\title{
AGRONEGÓCIO E DEPENDÊNCIA: UMA PERSPECTIVA DE ANÁLISE SOBRE A REGIÃO DO MATOPIBA
}

\author{
Glaycon Vinicios Antunes de Souza \\ Universidade Estadual de Campinas, Instituto de Geociências, Campinas, SP, Brasil \\ glayconantunes@hotmail.com
}

\author{
Laís Ribeiro Silva \\ Universidade Federal de Uberlândia, Instituto de Geografia, Pós-Graduação em Geografia, Uberlândia, \\ MG, Brasil \\ silva.laisrs@gmail.com
}

\begin{abstract}
RESUMO
O agronegócio no início deste século vem passando por transformações em sua constituição, que acompanharam as reformulações do sistema capitalista, cada vez mais internacionalizado e financeirizado. Esse processo implica em uma reorganização produtiva do território, que viabiliza a formação de regiões especializadas na produção de commodities agrícolas, como o MATOPIBA (formada por porções dos estados do Maranhão, Tocantins, Piauí e Bahia). É possível perceber, a partir da análise de regiões como o MATOPIBA, que o aprofundamento das relações de produção vincula-se a um contexto maior de reafirmação da posição dependente do Brasil na divisão internacional do trabalho, que tem como base a centralidade da produção de commodities na pauta exportadora. Trata-se de um processo que traz implicações para o território, como situações de superexploração do trabalho e dos recursos naturais, aqui compreendida através de revisão bibliográfica e análise de dados secundários. O objetivo desse trabalho foi indicar como o surgimento de regiões competitivas agrícolas pode estar relacionado com a questão da reafirmação da dependência no contexto internacional. A principal conclusão é que o processo de expansão do agronegócio globalizado (a partir de 2000) no MATOPIBA vem acirrando a vulnerabilidade do território.
\end{abstract}

Palavras-chave: Superexploração do trabalho. Superexploração de recursos naturais. Regiões competitivas agrícolas. Usos do território.

\section{AGRIBUSINESS AND DEPENDENCE: A PERSPECTIVE OF ANALYSIS ABOUT MATOPIBA REGION}

\begin{abstract}
The Agribusiness, since the beginning of this century, has been passing by transformations in its constitution, which follow the reformulations of the capitalist system, increasingly internationalized and financialized. This process implies a productive reorganization of the territory, which makes feasible the formation of specialized regions in the production of agricultural commodities, such as the region of MATOPIBA (a region formed by portions of the states of Maranhão, Tocantins, Piauí and Bahia). It is possible to understand from the analysis of regions such as MATOPIBA that the deepening of the relations of production binds itself to a greater context of reaffirmation of the Brazilian dependent position on the international division of labor, based on the centrality of commodities production to the export agenda. It is a process that has implications for the territory, such as situations of overexploitation of labor and natural resources, which we understood through literature review and analysis of secondary data. The aim of this paper was to indicate how the emergence of specialized regions could relate to the reinforcement of dependence in the international context. The main conclusion is that the process of expansion of globalized agribusiness (since 2000) in MATOPIBA has been intensifying the vulnerability of the territory.
\end{abstract}

Keywords: Overexploitation of work. Overexploitation of natural resources. Agricultural competitive region. Use of territory. 


\section{INTRODUÇÃO}

Nesse início de século novas configurações se afirmam no território brasileiro, sobretudo nos espaços agrícolas racionalizados com as dinâmicas globais de produção. Observamos uma nova situação dos complexos agroindustriais com a reestruturação das atividades produtivas que incluem práticas como - aprofundamento da especulação fundiária realizada por grandes corporações nacionais e internacionais, a financeirização cada vez maior dos agentes do setor, e a rearticulação da atuação do Estado como agente central da viabilização técnica e normativa para o agronegócio. Esse agronegócio se configura, tal como afirma Delgado (2012), como um novo pacto da economia política entre o mercado e o Estado que busca uma estratégia articulada com o capital financeiro para sustentação e reprodução das práticas agrícolas hegemônicas, tal como ocorrem. Essa estratégia vem culminando em uma reafirmação da primarização da pauta exportadora brasileira (com foco em commodities agrícolas e minerais) como modo de inserção do Brasil na divisão internacional do trabalho.

Esse processo pode ser percebido geograficamente a partir da formação de regiões especializadas na produção dessas mercadorias voltadas para o mercado externo, como por exemplo a porção do território brasileiro atualmente compreendida como o MATOPIBA (região que engloba áreas do Maranhão, Tocantins, Piauí e Bahia). A conformação desta situação foi chamada incialmente, no âmbito acadêmico, de BAMAPITO (BERNARDES, 2009) ou Cerrados do Centro Norte (ALVES, 2015). Com o intuito de oficializar a região como recorte espacial estratégico, o Estado brasileiro delimita através da EMBRAPA (Empresa Brasileira de Pesquisa Agropecuária), uma área prioritária de planejamento das atividades agropecuárias no Nordeste brasileiro, chamada de MATOPIBA. Esta região se caracteriza em termos produtivos pelo o aumento da especialização na produção de grãos, bem como o aprofundamento da especulação fundiária.

Neste trabalho reside o esforço inicial de articulação teórica entre a Geografia e a Economia, dois campos científicos que analisam instâncias sociais distintas, mas que são essenciais para a compreensão da totalidade do espaço socialmente produzido. Nesse sentido, alguns elementos de subordinação econômica e política analisadas na década de 1970 por Ruy Mauro Marini permanecem hoje com novas configurações, como a superexploração do trabalho e dos recursos naturais, que são mecanismos de competitividade que culminam em situações de vulnerabilidade territoriais.

Para a análise do avanço da fronteira do agronegócio na região do MATOPIBA e a conformação das regiões competitivas agrícolas, utilizou-se dados secundários obtidos através da Pesquisa Agrícola Municipal. No que diz respeito a análise da subordinação do território às lógicas exógenas, utilizou-se os dados da balança comercial brasileira obtida através do extinto Ministério da Indústria, Comércio Exterior e Serviços. Para verificação das situações de superexploração dos recursos naturais e do trabalho, foram utilizados respectivamente dados do Ministério do Meio Ambiente, da Comissão Pastoral da Terra e também reportagens.

Através destes dados e da revisão teórica proposta, tem-se como objetivo debater e analisar a configuração atual do setor agrícola brasileiro como forma de afirmação da inserção dependente do Brasil na economia mundial, que pode ser compreendida através da materialização de regiões competitivas agrícolas e situações de vulnerabilidade no território (CASTILLO, 2008) como o MATOPIBA.

\section{CONDICIONANTES DO AGRONEGÓCIO BRASILEIRO NO SÉCULO XXI}

A partir dos anos 2000 Guilherme Costa Delgado (2012) reconhece uma nova configuração nas relações econômicas e políticas no campo brasileiro, fruto dos esforços públicos e privados em gerar saldos comerciais externos para suprir o déficit da conta corrente, e em efetivar uma estratégia econômica de acumulação de capital a partir do sistema financeiro.

Esse processo está relacionado com a conjuntura econômica brasileira do final do século $X X$ e as medidas adotadas nesse contexto. A economia brasileira sofreu com a crise de liquidez internacional em 1998, o que provocou fuga de capitais, e consequentemente mudanças no regime cambial. Como estratégia para superar esse impasse, além de recorrer a empréstimos do FMI (em 1999, 2001 e 2003), o governo Fernando Henrique Cardoso (FHC) adotou uma política comercial pautada na geração de saldo através do comércio exterior para suprir o déficit na conta corrente. Assim, os setores primários foram acionados novamente (como ocorreu em $1982 \mathrm{com}$ a crise da dívida) para

Caminhos de Geografia Uberlândia $\quad$ v. 20, n. $72 \quad$ Dez/2019 $\quad$ p. 149-168 Página 150


gerar saldo comercial, colocando o agronegócio como pauta central na política macroeconômica externa e na política agrícola interna brasileira (DELGADO, 2010).

Para o autor supracitado, cinco medidas políticas desenvolvidas no segundo governo de FHC foram importantes para esse processo. A primeira foi a ampliação e construção de nova infraestrutura logística (rodovias, ferrovias e portos) definidas como ação estratégica do Plano Plurianual de Governo (2000/2003), o que culminou no programa "Brasil em Ação". Muitas dessas obras foram retomadas no Programa de Aceleração do Crescimento (PAC), no governo Lula, bem como o investimento em pesquisa agropecuária via Empresa Brasileira de Pesquisa Agropecuária (EMBRAPA) em conformidade com as necessidades de grupos do agronegócio, o que configura a segunda medida. A terceira medida foi a regulação branda do mercado de terras e a quarta foi a mudança na política cambial que deixou mais competitiva a economia do agronegócio. A última e quinta medida foi a liberação de crédito rural a partir dos Planos Safra (DELGADO, 2010; 2012).

Essa nova configuração agrícola pode ser entendida como uma associação política entre a agricultura moderna, as cadeias agroindustriais, o sistema de crédito (sendo o Estado brasileiro um dos principais agentes neste setor) e o mercado de terras, com o objetivo de promover estratégias de acumulação no contexto de mundialização financeira. Nas palavras do autor

[...] mercados organizados - de terras, de crédito, e dos complexos agroindustriais; e como esses mercados dependem essencialmente da regulação (ou desregulação, conforme o caso) e provisão estatal, o capital financeiro na agricultura irá se configurar como virtual pacto da economia política entre cadeias agroindustriais, grande propriedade fundiária e o Estado, tendo em vista viabilizar uma parceria estratégica. (DELGADO, 2012, p. 92).

Esse novo pacto (DELGADO, 2012) implicou em uma tendência de "primarização" da pauta exportadora brasileira que, politicamente baseada em questões das teorias econômicas clássicas, reforçou o que seria essa a vantagem comparativa "natural" do Brasil, o que reproduziu e reafirmou sua dependência aos países centrais da economia capitalista. Nesse contexto, após os anos 2000 o setor primário cresceu de forma significativa. Conforme dados do Ministério da Indústria, Comércio Exterior e Serviços (MIDC, 2017), o volume das exportações de commodities agrícolas vem aumentando consideravelmente (Figura 1).

Figura 1 - Volume $(\mathrm{kg})$ exportado de commodities agrícolas no Brasil - complexo da soja, carnes, açúcar e álcool, papel e celulose (2000 - 2016).

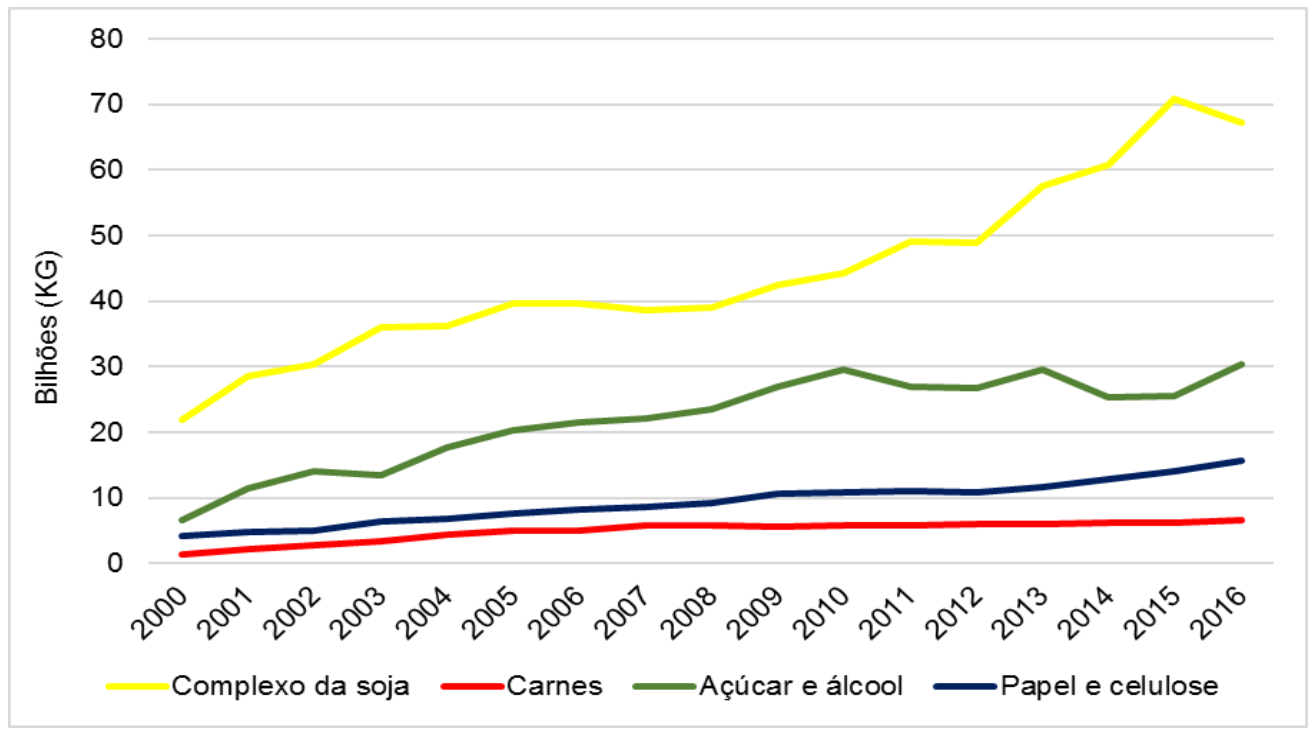

Fonte-MIDC, 2017; Org. Autores. 
As exportações agropecuárias vêm ocorrendo sobretudo nos de complexo da soja (grãos, farelo e óleo), de carnes (boi, ave, suína e peru) e de álcool e açúcar, papel e celulose. Entre os anos de 2000 e 2016 o crescimento aproximado destas mercadorias foram respectivamente de $505 \%, 625 \%$, $820 \%, 190 \%$. O aumento das exportações é uma das implicações de uma conjuntura internacional marcada pela valorização do preço das commodities agrícolas, bem como uma articulação interna entre o Estado e do mercado que buscaram estratégias para viabilizar a expansão do agronegócio no país.

Como debatido por Silva (2017a), o setor sucroenergético é um dos principais exemplos desta situação, de articulação entre o Estado e o mercado para o fortalecimento do agronegócio no país. Entre os anos de 2002 a 2015 o Estado, via Banco Nacional de Desenvolvimento Social (BNDES), liberou para o setor quase $\mathrm{R} \$ 34$ bilhões para gastos em diferentes ramos desta atividade como logística, pesquisa, infraestrutura, capital de giro e fundos, entre outros. Esta ação colaborou na reestruturação do setor a partir da oferta de financiamento para as grandes corporações nacionais e internacionais, notoriamente a Raízen, a Cosan, a Odebrecht Agroindustrial, o grupo São Martinho S.A, Logum Logística S.A, etc. De certa forma o investimento estatal viabilizou o processo de internacionalização da atividade sucroenergética, alcançada através de aquisições e fusões entre empresas brasileiras e estrangeiras.

O crescimento internacional do preço das commodities, o aumento das exportações, a reestruturação das redes agroindustriais no país, bem como a crise financeira de 2008, vem promovendo a valorização fundiária no Brasil e com isso um novo conjunto de agentes estão ampliando e diversificando seus investimentos para o mercado de terras, com a finalidade de obter maior quantidade de capital. Como discutido por Bernardes et al. (2017) nos últimos 15 anos há o surgimento de uma nova safra do capitalismo no campo brasileiro, devido ao aprofundamento da atuação de empresas vinculadas ao mercado financeiro como os fundos de investimentos (pensão, hedge, soberanos, etc.) no mercado de terras, culminando no fenômeno que se convencionou chamar de land grabbing (fenômeno que não se restringe ao Brasil e atinge diversas regiões do mundo).

A principal característica deste fenômeno é o controle e a concentração de significativas áreas de terras e de recursos (água, minerais e florestais) por corporações substancialmente alicerçadas pelo capital financeiro e especializadas na compra, valorização e venda de propriedades agrícolas, como uma estratégia para obtenção de maiores rendimentos. Frederico e Gras (2017, p. 18), apoiados em Borras Jr. et al. (2012), debatem que o entendimento de land grabbing supõe primeiramente

[...] transferência do controle da terra, assim como de outros recursos (hídricos, minerais e florestais) a novos agentes. Em segundo lugar, comporta grandes escalas não somente de terras, mas principalmente de capital. Finalmente, ocorre no marco - ao mesmo tempo em que é resultado - da convergência de múltiplas crises (alimentar, energética financeira e ambiental) em que o grande capital desenvolve dinâmicas de acumulação nas quais a terra adquire centralidade. (FREDERICO; GRAS, 2017, p.18)

Esta configuração é um dos reflexos da financeirização da economia, em que cada vez mais o capital financeiro cria novas formas para se retroalimentar, cuja principal marca é a presença de agentes do capital financeiro em atividades consideradas como "alternativas", sendo o mercado fundiário e consequente especulação de terras um exemplo.

No Brasil observamos este processo a partir de empresas criadas especificamente para o propósito de obter renda a partir da especulação fundiária. Geralmente, essas empresas são oriundas da associação de corporações vinculadas a atividade agrícola propriamente dita com outras voltadas para a especulação financeira (fundos de investimentos). Entre as maiores empresas deste setor do agronegócio pode-se destacar a Sollus Capital, Radar S/A, Adecoagro, Brasil Agro, SLC Agrícola, conjuntamente essas empresas possuem mais de 830 mil hectares (ha) de terras (PITTA; MENDONÇA, 2015; SOUZA, 2017) em diferentes porções do país, em especial nas áreas de fronteiras agrícolas do domínio morfoclimático dos Cerrados (AB'SABER, 2003), em regiões do Centro Oeste, Norte e Nordeste. Nessas áreas encontram terras com preços baixos. Bernardes e Mendonça (2017) acrescentam que o baixo preço das terras nas fronteiras agrícola nos Cerrados está relacionado ao

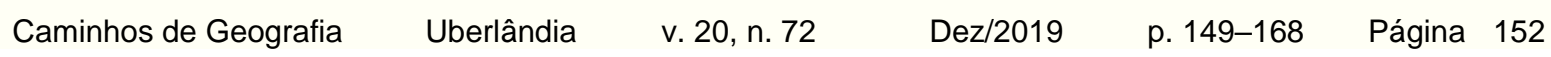


[...] fato de ainda não terem sido preparadas para as atividades agrícolas modernas, por sua localização, seja em relação à logística dos portos de escoamento, aos grandes centros de produção agrícola ou de consumo produtivo; por estarem localizadas em áreas de precária infraestrutura, as quais geralmente se encontram sob responsabilidade do Estado ou dependentes de sua concessão; por situarem em regiões de instabilidade política; por apresentarem problemas de titulação. (BERNARDES e MENDONÇA, 2017, p. 58)

A partir da análise relacional entre os diferentes agentes que compõem o agronegócio, podem-se compreender as estratégias de acumulação da agricultura exercidas no contexto de um novo pacto da economia política do agronegócio (DELGADO, 2012). Para além da avaliação da relação entre os distintos setores do agronegócio é relevante compreendermos como o território é acionado e viabilizado para a ampliação da acumulação, assim o entendimento de agricultura científica globalizada (SANTOS, 2001) nos possibilita investigar tal situação.

Para Santos (2001), visualiza-se uma verdadeira agricultura científica globalizada no campo brasileiro, que responde aos mesmos imperativos que ditam a dinâmica econômica e política de outras atividades produtivas. Essa nova configuração da agricultura se realiza a partir de um conjunto de objetos carregados de conteúdos técnicos, científicos e informacionais, induzindo ao aumento da produtividade agrícola, e assim, possui uma referência em nível global, devido ao seu caráter competitivo.

Frederico (2015) compreende a agricultura científica globalizada como a manifestação geográfica do agronegócio do período técnico-científico-informacional (SANTOS, 2001, 2002), cujo dinheiro em estado puro passa a ser fundamental para a sua realização. Entendo o dinheiro em estado puro como acumulação em si mesmo (SANTOS, 2001), é o capital que "[...] busca 'fazer dinheiro' sem sair da esfera financeira, sob forma de juros de empréstimos, de dividendos e outros pagamentos recebidos a título de posse de ações e, enfim, de lucros nascidos de especulação bem-sucedido" (CHESNAIS, 2005, p. 35). É o que Chesnais (2010, apud MARX, 1894) chamou de "acumulação de capitaldinheiro propriamente dita", que se opõe a "acumulação verdadeira de capital" que resulta, ao final, em uma acumulação de capital fictício. Assim, o dinheiro torna-se um dado onipresente, uma informação indispensável na regulação da atividade que visa ser competitiva, sendo necessário para a agricultura científica globalizada. Trata-se da face das atividades agrícolas inseridas em um mercado mundializado e financerizado, característico da forma em que o capitalismo adquire no período contemporâneo.

Toda essa configuração da economia política do agronegócio no país vem reafirmando a relação de dependência com as economias centrais do capitalismo, sinalizando a condição de subordinação com as lógicas estabelecidas fora do território, implicando em uma situação de vulnerabilidade frente a condições que tendem a fugir do controle da nação.

\section{NEXOS ENTRE GLOBALIZAÇÃO, AGRONEGÓCIO E DEPENDÊNCIA}

\section{TEORIA DA DEPENDÊNCIA}

As ações do Estado brasileiro voltadas para o agronegócio nesse início de século, possibilitaram o posicionamento atual da produção de commodities agrícolas como central para a economia. Têm-se então um esforço, legitimado e fomentado pelo Estado, em primarizar cada vez mais a pauta exportadora como estratégia de competitividade do país no mercado internacional, o que acarreta consequências que são oriundas do próprio modo como esse tipo de produção ocorre: concentração fundiária, monocultura (uma vez que, por se tratar de produtos com baixo valor agregado, necessitam ser cultivados em larga escala para compensar investimentos e conseguir lucros significativos) e superexploração dos recursos naturais e do trabalho, resultado da busca incessante por maior produtividade.

Nesse contexto, o território é acionado para suprir demandas exógenas através de atividades cada vez mais controladas por agentes estrangeiros, culminando em um uso corporativo do território. Essa relação apenas é permitida pela dinâmica do capitalismo contemporâneo, e reforçam a inserção dependente da economia brasileira na divisão internacional do trabalho (MARINI, 1973).

[...] a visão é a de que as relações de produção (desenroladas a partir do processo de integração das economias nacionais ao mercado global) são baseadas no

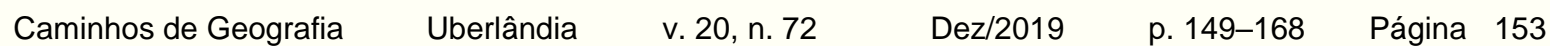


controle do mercado por parte das nações hegemônicas e isso leva à constituição de mecanismos de transferência de valor entre as economias periféricas e central, de modo que a mais-valia produzida na periferia é apropriada e acumulada no centro (AMARAL, 2013, n.p.).

Ao trabalhar com a teoria da dependência, Marini (1973) afirma que a formação econômica dos países da América Latina se insere de forma dependente no cenário internacional desde o início do seu desenvolvimento, no momento de expansão comercial no século XVI. O próprio desenvolvimento comercial e bancário dos países da Europa possui ligação direta com o fluxo comercial colôniametrópole que se estabeleceu desde aquele momento. O papel das colônias na América Latina como fornecedoras de matérias-primas se manteve mesmo após os processos de independência dos países e, por esse fator, os Estados nacionais já surgiram com significativos nexos de dependência junto aos países centrais da economia capitalista.

Assim se estabelece uma situação de troca desigual entre matéria-prima (ou o que hoje denominamos por commodities) dos países dependentes e bens manufaturados dos países centrais da economia capitalista, que tem o seguinte desdobramento:

[...] as nações desfavorecidas pela troca desigual não buscam tanto corrigir o desequilíbrio entre os preços e o valor de suas mercadorias exportadas (o que implicaria um esforço redobrado para aumentar a capacidade produtiva do trabalho), mas procuram compensar a perda de renda gerada pelo comércio internacional por meio do recurso de uma maior exploração do trabalhador (MARINI, 1973, n.p.).

É assim que, segundo Marini (1973), se estrutura a situação de dependência, entendida pelo autor como uma relação de subordinação entre nações independentes, que é retroalimentada por relações de produção que são restabelecidas para garantir a reprodução da própria situação de dependência.

Até mesmo o movimento mais recente de inserção dos países da América Latina, e consequentemente do Brasil, no processo de financeirização teria ocorrido de modo a reafirmar a dependência aos países centrais da economia capitalista. Isso porque essa inserção ocorre de modo a perpetuar 0 endividamento dos países dependentes, o que implica na proliferação de dívidas impagáveis:

O modo como as economias periféricas, em particular as latino-americanas, se inserem nesse processo de financeirização é subordinado desde a sua origem. Tal inserção se coloca quando do recurso ao capital externo durante o período desenvolvimentista na América Latina e da forte entrada desses capitais, fruto da alta liquidez internacional e do processo de "reciclagem dos petrodólares", de tal forma que o endividamento externo das economias latino-americanas salta para níveis sem precedentes, inicialmente por conta das necessidades criadas pelo choque do petróleo em 1973, depois pelo processo de realimentação produzido pelo chamado choque dos juros internacionais, dando origem à crise da dívida dos anos 1980 (AMARAL, 2013, n.p.).

Assim, podemos afirmar que a inserção dos países latino americanos, por exemplo, se deu inicialmente de forma passiva e controlada por lógicas exógenas. No entanto, com a inserção da ideologia neoliberal nas práticas político-econômicas, e o consequente processo de desregulamentação e abertura de mercados, podemos dizer que há uma postura mais ativa do país na dinâmica financeira internacional, o que não necessariamente quer dizer uma inserção mais independente, uma vez que os centros de decisão do capital financeiro estão nos países centrais da economia capitalista (AMARAL, 2013).

Nesse contexto é preciso destacar a atuação de um conjunto de corporações especializadas na especulação fundiária no país, que são oriundas de investimentos internacionais e nacionais. Uma das principais características dessas empresas é o alto nível de capitalização provindo de setores que não atuavam na atividade agrícola, como os fundos de investimentos, fundos de pensões, fundos de hedge, entre outros, que buscam uma estratégia de acumulação a partir do capital financeiro visando a valorização do preço das terras. A razão desse processo é a necessidade cada vez maior e imediata de remuneração dos agentes financeiros, que buscam o aumento da mais-valia provinda por meio da superexploração do trabalho e dos recursos naturais.

Caminhos de Geografia Uberlândia $\quad$ v. 20, n. $72 \quad$ Dez/2019 $\quad$ p. 149-168 Página 154


Para Marini (1973), a superexploração do trabalho pressupõe três mecanismos: "[...] a intensificação do trabalho, a prolongação da jornada de trabalho e a expropriação de parte do trabalho necessário ao operário para repor sua força de trabalho [...]" (MARINI, 1973, n.p.). Segundo o autor estes três mecanismos possuem uma característica comum, que é o fato de não permitirem ao trabalhador repor o desgaste da sua força de trabalho:

[...] nos dois primeiros casos, porque lhe é obrigado um dispêndio de força de trabalho superior ao que deveria proporcionar normalmente, provocando assim seu esgotamento prematuro; no último, porque lhe é retirada inclusive a possibilidade de consumo do estritamente indispensável para conservar sua força de trabalho em estado normal. Em termos capitalistas, esses mecanismos (que ademais podem se apresentar, e normalmente se apresentam, de forma combinada) significam que o trabalho é remunerado abaixo de seu valor e correspondem, portanto, a uma superexploração do trabalho. (MARINI, 1973, n.p.).

A própria característica territorial do Brasil permitiu que a expansão das atividades agrícolas gerasse um conjunto de ativos com baixos custos, prontos para serem empregados em um uso lucrativo. Para Delgado (2012), os ganhos de produtividade decorrentes da exploração de novos recursos naturais (como o que ocorre com a expansão territorial das commodities agrícolas) ou da intensificação do pacote tecnológico, foram importantes bases da inserção especializada do Brasil na divisão internacional do trabalho após os anos 2000. Assim, a inserção dependente da economia brasileira no mercado internacional e a consequente primarização da pauta exportadora nas últimas décadas, conjugadas a dinâmica do capitalismo financeiro, levou não apenas a superexploração do trabalho, mas também a expropriação e superexploração dos recursos naturais:

A expansão das exportações de commodities agrominerais, que é impelida pela pressão para remuneração do capital estrangeiro (o déficit dos "serviços") e pela perda da competitividade da maioria dos setores industriais, ressalta a presença de estruturas de acumulação de capital e captura do excedente econômico, fortemente ancorada na teoria das vantagens comparativas naturais e da produtividade dos recursos da terra e das jazidas (DELGADO, 2012, p. 114).

A superexploração dos recursos naturais promove a degradação do meio ambiente. $O$ aumento das queimadas, desmatamentos e consequentemente da emissão de dióxido de carbono na atmosfera, bem como a intensificação do uso de agrotóxicos são alguns dos procedimentos que acarretam implicações severas ao meio ambiente, como a perda da biodiversidade. Estes casos estão relacionados com a expansão do monocultivo de commodities agrícolas (DELGADO, 2012). São fatores que, como afirma Delgado (2012), não entram no cálculo da produção agrícola e que acarretam custos sociais significativos.

Todos esses fatores criam condições para o surgimento de regiões especializadas na produção de determinadas commodities, sobretudo as mais valorizadas para a exportação, em que as condições técnicas e políticas são elaboradas para tornar a atividade cada vez mais competitiva e integradas como a economia internacional. Estas regiões são umas das expressões geográficas que de certa forma, nos evidencia o posicionamento subordinado do Brasil na economia internacional. Trata-se de um conjunto de articulações econômicas, técnicas e políticas que são tecidas para o fortalecimento do agronegócio e cuja regulação produtiva geralmente é realizada em lugares distantes do local onde a produção propriamente dita se efetiva. Neste sentido, o entendimento de região competitiva agrícola (CASTILLO, 2008) nos auxilia a compreender como o território brasileiro é usado e ordenado para a articulação com a economia internacional.

\section{GLOBALIZAÇÃO E REGIÕES COMPETITIVAS AGRÍCOLAS}

No atual período de globalização e de fragmentação territorial, observamos a expansão das áreas agrícolas nos Cerrados brasileiros e a lógica da produção extravertida (imperativo das exportações próprio da produção de commodities agrícolas), acarretando no distanciamento das regiões produtoras dos centros consumidores, bem como no aumento da distância dos portos. Conforme Santos (1999, 2001, 2002), a globalização é sustentada por três fenômenos que se interrelacionam, que são: a convergência dos momentos (unicidade do tempo), unicidade da técnica e o motor único a mais valia universal. A convergência dos momentos é entendida pela facilidade, rapidez e

Caminhos de Geografia Uberlândia $\quad$ v. 20, n. $72 \quad$ Dez/2019 $\quad$ p. 149-168 Página 155


simultaneidade instantânea em que a informação pode chegar a diferentes lugares, é a oportunidade de comunicar à distância, de interligar e comandar a produção através das atividades financeiras, que se torna uma informação, é a possibilidade de percebermos o acontecer planetário. O atual período é marcado pela técnica da informação - cibernética, internet, computadores, fibra ótica, satélites, informática, microeletrônica, entre outros - atingindo (ou como coloca o autor, invadindo) de forma estratégica e seletiva pontos dos territórios em diversas porções do globo, proporcionando certa "homogeneização" técnica no planeta.

O surgimento de novos objetos técnicos não implica no desaparecimento das famílias de técnicas precedentes, "[...] o novo conjunto de instrumentos passa a ser usado pelos novos atores hegemônicos, enquanto os não hegemônicos continuam utilizando conjuntos menos atuais e menos poderosos" (SANTOS, 2001, p. 25). Os sistemas de objetos na atualidade possibilitam que a informação produzida em um determinado lugar chegue a diferentes pontos do globo terrestre de forma instantânea (unicidade do tempo), assegurando a existência do capital financeiro e suas conexões em diferentes partes do mundo de forma constante, incessante e imediata, viabilizando uma mais-valia mundial.

Entende-se como motor da vida social a mais-valia mundial, devido à "imposição de um mercado global, fundado no intercâmbio global e numa lei do valor universal" (DOS SANTOS, 1993 apud SANTOS, 1999, p. 09). A mais-valia em nível global é assegurada pela ação convergente das grandes organizações (empresas multinacionais e os bancos transnacionais), sejam nacionais ou supranacionais, públicas ou privadas, promovidas pela unicidade das técnicas. Assim, tudo se internacionaliza, a produção, a circulação, o consumo, a cultura, o crédito, o dinheiro, entre outros, devido à atuação sistêmica das grandes corporações e agências supranacionais que regulam a atividade econômica e social dos lugares em todo o planeta (SANTOS, 2002).

A reestruturação produtiva agrícola no Cerrados é resultante de eventos modernizadores que implica na especialização regional. Essas regiões passam por significativas modificações em sua composição técnica e política, derivando em novos arranjos regionais produtivos, promovidos pelo aprofundamento das redes agroindustriais, conformando verdadeiras regiões produtivas do agronegócio (ELIAS, 2011). O grau de competitividade de tais regiões pode variar de acordo com as disponibilidades matérias e normativas existente, permitindo maior integração com mercados internacional, crescimento da rentabilidade lucrativa e redução de custos aos agentes que estabelecem nexos produtivos na região (CASTILLO, 2008).

Assim uma das expressões geográficas decorrentes do agronegócio globalizado, que impõem às regiões novas formas organizacionais e novas coesões organizacionais, são as regiões competitivas agrícolas (CASTILLO, 2008; CASTILLO e FREDERICO, 2010a). No atual período as relações produtivas são estabelecidas com um único propósito: a defesa dos interesses próprios de cada empresa e cada pessoa, fundamentando o egoísmo e o individualismo que é marca da nossa sociedade. Contudo, a competitividade não é um atributo apenas das pessoas e empresas, esta ideologia torna-se fundamento dos lugares e regiões a partir da distribuição desigual da densidade normativa e técnica. Neste sentido a proposição de regiões competitivas configura-se como uma elaboração conceitual acertada para compreendermos as compartimentações geográficas resultantes da agricultura científica globalizada, e de suas lógicas de subordinação às demandas internacionais.

A região competitiva agrícola caracteriza-se como um recorte do espaço geográfico onde a atividade do agronegócio é muito relevante, tendo densidade normativa (flexibilidade fiscal e financeira, selos de denominação de origem, políticas de modernização do campo, entre outros) e técnica (infraestrutura de circulação e distribuição, maquinário agrícola, agroindústrias, etc.) para promover o aprofundamento do agronegócio (CASTILLO e FREDERICO, 2010a). Esta prática agrícola é obediente a parâmetros internacionais de produção quanto ao custo e qualidade.

Para Castillo e Frederico (2010b), a logística neste período é um instrumento ainda mais relevante no processo de circulação corporativa, sendo indispensável para a competitividade e, do mesmo modo, para compreensão de uma região competitiva agrícola. Ou seja, "as regiões competitivas derivam exatamente da integração reticular de determinadas áreas do território aos mercados internacionais" (FREDERICO, 2012, p. 11). A logística pode ser compreendida como sinônimo de circulação corporativa, viabiliza a circulação/fluxo dos produtos através de sistemas de engenharia que em sua maioria são criados pelo poder público.

Caminhos de Geografia Uberlândia $\quad$ v. 20, n. $72 \quad$ Dez/2019 $\quad$ p. 149-168 Página 156


Em síntese, a dimensão geográfica de logística pode ser definida a partir de três componentes: material (objetos geográficos - rodovias, ferrovias, armazéns, portos, entre outros), normativa (ações público-privadas, concessões, pedágios, entre outros) e organizacional (acesso privilegiado às informações especializadas do setor), "[...] que, reunidas em um subespaço, conferem fluidez e competitividade aos agentes e aos círculos espaciais produtivos. Trata-se da versão atual da circulação corporativa" (CASTILLO, 2011, p. 340). Essa é a situação geográfica que verifica-se nos Cerrados nas regiões Norte e Nordeste na área denominada de MATOPIBA.

\section{MATOPIBA E ESPECIALIZAÇÃO REGIONAL PRODUTIVA DO AGRONEGÓCIO}

A partir dos anos 2000, constata-se de forma mais evidente a constituição do MATOPIBA como uma região especializada na produção de commodities agrícolas, sobretudo em grãos. Mas, sua configuração geográfica enquanto moderna região do agronegócio não se dá a partir dos anos 2000. Os eventos que propiciaram a atual situação geográfica no MATOPIBA são resultados de articulações políticas e econômicas anteriores, quando grandes produtores e empresas nacionais e internacionais começam a chegar à região. Estes instalaram em porções do território que historicamente foram ocupados pelas populações consideradas "tradicionais" (quilombolas, comunidades indígenas, geraizeiros, vazanteiros, entre outros). Esta ocupação se deu, sobretudo, nos topos de chapadas que são áreas propícias para a mecanização produtiva por serem compartimentações geomorfológicas planas, o que facilita a circulação das máquinas agrícolas (ALVES, 2006). Tal processo ocorreu em meados de 1980, na Bahia, e início dos anos 1990, nos demais estados que compõem o MATOPIBA. Além do mais, devemos mencionar a atuação do Estado na produção de condições materiais (infraestrutura logística - rodovias, ferrovias, portos, desenvolvimento de pesquisa de biotecnologia, financiamento agrícola, etc) e imateriais (desenvolvimento de políticas de incentivo a expansão da agricultura moderna, criação de discursos de modernização dos Cerrados, entre outros) para o aprofundamento do agronegócio na região.

Assim, três décadas atrás predominava uma agricultura caracterizada por uma situação de baixa densidade técnica (maquinário agrícola moderno), com pouco empenho científico e de capital, onde a dinâmica da natureza predominava e ditava o ritmo da produção. Esta condição vem se transitando para uma lógica global devido ao uso de um conjunto de objetos técnicos como plantadeiras, colheitadeiras, arados, sistemas de irrigação, entre outros, bem como a inserção cada vez maior do conhecimento científico na produção agrícola (biotecnologia, agronomia, zootecnia, medicina veterinária, entre outros). O adensamento técnico possibilitou o aumento da produtividade de cultivos voltados para o mercado externo, e configurou a atividade como uma agricultura científica globalizada, especificamente nos anos 2000, o que atraiu cada vez mais o interesse de grandes corporações do setor para a região, um dos principais agentes deste processo. A modernização técnica da atividade agrícola está dotando esta área do território com novos recursos, materiais, de ideias, valores e sentimentos, inserindo a região a uma nova dinâmica produtiva.

Diante desta situação, verificamos que a partir dos anos de 1990 o crescimento da quantidade de produtos agrícolas para exportação, em especial os grãos como soja e milho, bem como o algodão, que alcançam significativo aumento a partir dos anos 2000 (Tabela 1). Segundo dados da Produção Agrícola Municipal, disponível no Sistema do Instituto Brasileiro de Geografia e Estatística de Recuperação Automática (SIDRA/IBGE, 2016), a produção de soja em 1990 foi de aproximadamente de 300 mil toneladas (t), passando para quase 8,6 milhões de t, em 2014. Ainda destacamos que aproximadamente $11 \%$ da soja produzida no Brasil em 2014 foi colhida na região do MATOPIBA, quantidade expressiva se considerarmos que em 1990, esta mesma produção representava cerca de $1 \%$ da produção nacional. A expansão da fronteira agrícola pode ser mensurada a partir do aumento da área colhida, entre 1990 e 2014, somente o cultivo de soja teve um crescimento aproximado de $716 \%$, ou seja, passou de 403 mil ha para mais de 3 milhões de ha.

A quantidade produzida de milho assim como a de soja, vem passando por significativo aumento em sua produção. Em 1990, a quantidade produzida era de quase 190 mil t, crescendo para quase 5,2 milhões de $t$ em 2014. A área colhida de milho entre 1990 e 2014 aumentou 115\%, acima do crescimento brasileiro que foi $35 \%$. Percebe-se que no MATOPIBA há a expansão concomitante da arena da produção, compreendida como aumento dos hectares da produção propriamente dita, bem como da área de produção considerada como o "[...] espaço utilizado para a produção de um

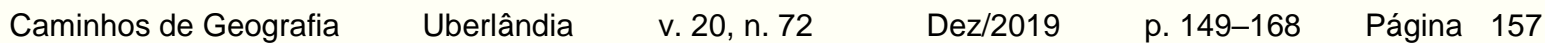


determinado produto, desde a produção em si até o consumo final" (CASTILLO e FREDERICO, 2010b, p. 469), visto que parte da produção é enviada para o mercado externo.

Tabela 1 - Quantidade produzida, área colhida e valor da produção das principais commodities agrícolas no MATOPIBA.

\begin{tabular}{lcccc}
\hline \multicolumn{5}{c}{ Quantidade produzida (toneladas) } \\
\hline Cultivos & 1990 & 2000 & 2014 & Crescimento (\%) entre 1990 e 2014 \\
Soja & 260.624 & 2.208 .221 & 8.642 .199 & 3.215 \\
Milho & 189.796 & 1.319 .112 & 5.292 .925 & 2.688 \\
Algodão herbáceo & 8.920 & 124.262 & 1.288 .536 & 14.345 \\
\hline \multicolumn{5}{c}{ Área colhida (hectares) } \\
Cultivos & 1990 & 2000 & 2014 & Crescimento (\%) entre 1990 e 2014 \\
Soja & 403.070 & 904.995 & 3.291 .778 & 716 \\
Milho & 499.856 & 486.739 & 1.073 .853 & 114 \\
Algodão herbáceo & 16.295 & 41.574 & 357.798 & 2.095 \\
\hline & Valor de produção (R\$ mil) & & Crescimento (\%) entre 1994 e 2014 \\
Cultivos & 1994 & 2000 & 2014 & 4.706 \\
Soja & 170.445 & 581.933 & 8.192 .283 & 2.566 \\
Milho & 79.293 & 228.345 & 2.114 .586 & 126.000 \\
Algodão herbáceo & 2.642 & 82.197 & 3.331 .552 & \\
\hline
\end{tabular}

Fonte - SIDRA/IBGE, 2016. Org.: Autores.

Mesmo que a produção e a área colhida do algodão na região sejam quantitativamente menores, se comparada as outras commodities agrícolas de exportação, esta foi a commodity que mais cresceu em termos relativos tanto na quantidade produzida, área colhida e valor, como visto na Tabela 1. Contudo, a produção de algodão no MATOPIBA está concentrada no Oeste baiano, somente esta sub-região foi responsável por $66 \%$ da área colhida da região. Cabe destacar que o cultivo de algodão no Oeste baiano não possui relevância apenas no contexto regional, era a segunda maior região produtora desta commodity no país, ficando atrás apenas da região norte mato-grossense que produziu pouco mais de 1,3 milhões de toneladas em 2014 (SIDRA/IBGE, 2016).

Sem dúvida a soja é a commodity que mais contribui com a economia regional, tendo em vista que a produção obteve um valor de $\mathrm{R} \$ 8$ bilhões em 2014. Neste sentido a produção de soja é o carrochefe na abertura da fronteira agrícola (BERNARDES, 2009). Segundo dados do IBGE (2016) em 1990 apenas seis municípios obtiveram produção de soja acima de $10 \mathrm{mil} \mathrm{t}$, maior parte localizados no Oeste baiano com destaque para São Desidério que produziu quase $92 \mathrm{mil}$ t; na década seguinte o número de municípios com esta quantidade produzida chegou a 21 , a importância do Oeste da Bahia foi ainda maior, pois somente Barreiras e São Desidério colheram quase 1 milhão de t de soja.

Contudo a expansão da produção atingiu várias porções do MATOPIBA como alguns municípios do Piauí (Uruçuí e Baixa Grande do Ribeiro), Tocantins (Pedro Afonso, Formoso do Araguaia e Campos Lindos), e em especial o sul do Maranhão (Balsas, Tasso Fragoso, Sambaíba, Riachão, entre outros), isso em 2000. E por fim, em 2014 a produção de soja superior a 10 mil t ocorreu em 85 municípios em diversas sub-regiões do MATOPIBA, chegando a áreas mais ao norte da região como os municípios maranhenses de Brejo e Anapurus (Figura 2).

Com o aumento da produção no MATOPIBA o Estado vem investindo recursos financeiros em uma série de infraestrutura para viabilizar a fluidez corporativa. Dentre os principais investimentos em logística feito nos últimos anos pelo Estado destaca-se a expansão da malha da Ferrovia Norte/Sul, no estado do Tocantins e Maranhão, bem como a própria modernização do Porto de Itaqui, um dos principais portos para o embarque das commodities produzidas no MATOPIBA. 
Conforme Fornaro (2012), a Ferrovia Norte/Sul foi idealizada na década de 1980, com interesse de integrar territorialmente o país no sentido Norte/Sul, contudo sua implementação se deu aquém do esperado, isso até os anos 2000 quando o projeto passa a ser importante para escoar a produção agrícola do Tocantins, Maranhão e Piauí.

Figura 2 - Expansão da produção regional de soja no MATOPIBA - por municípios (anos 1990, 2000 e 2014).

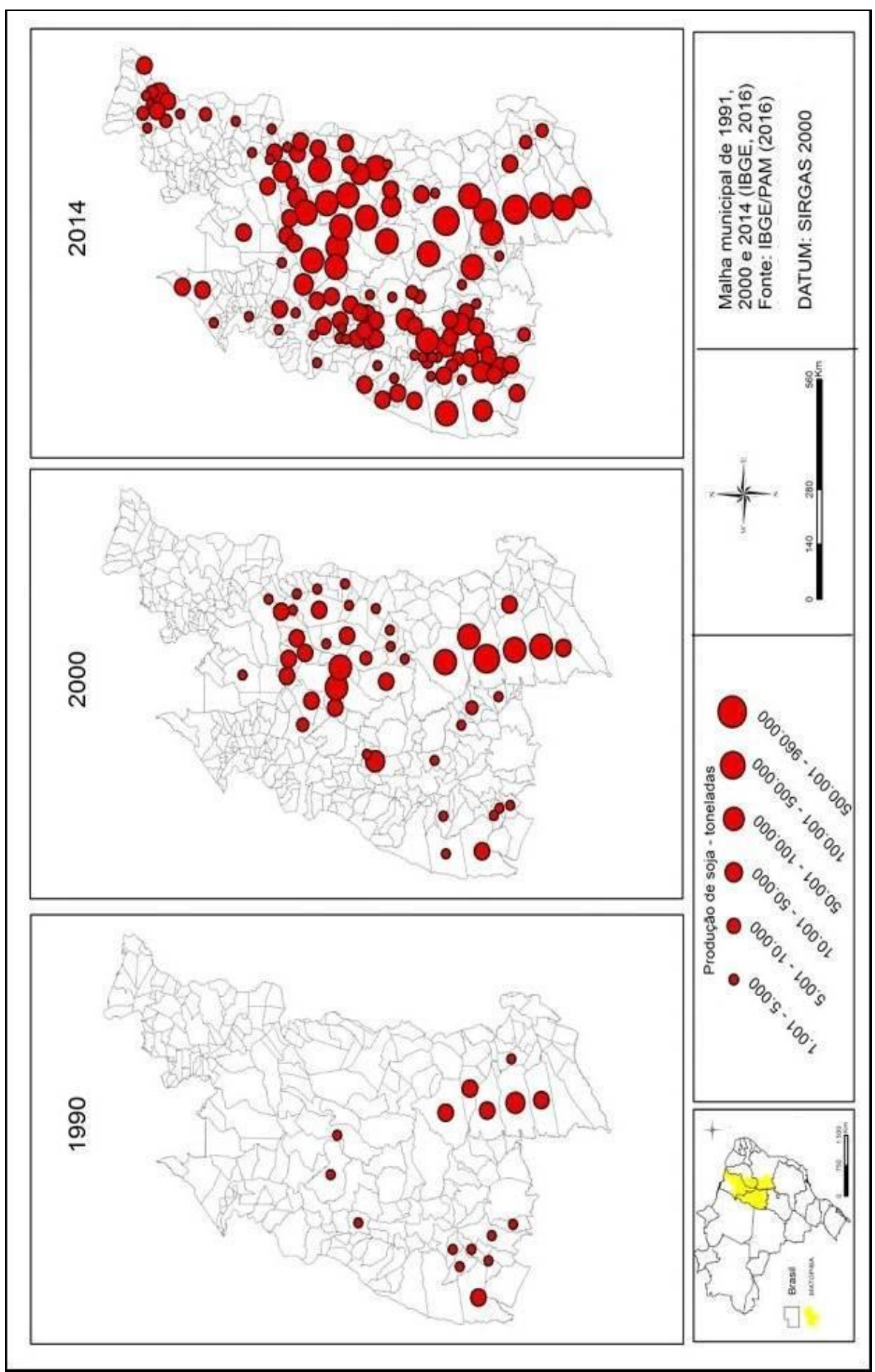

Fonte - IBGE/PAM, 2016. Org. SOUZA, G. A. V. 
Ainda segundo Fornaro (2012), até 2002 havia apenas $215 \mathrm{~km}$ da mencionada ferrovia no Tocantins e Maranhão, é a partir de recursos PAC que passa-se a observar uma intensa expansão da malha ferroviária. Entre 2007 e 2010 foram criados mais de 500 km de rodovia que conectam Aguiarnópolis (TO) à Palmas (TO). Em 2015 foi expandido em 855 km o trecho entre Palmas (TO) e Anápolis (GO). Para Vencovsky (2011), a Ferrovia Norte/Sul configura-se como a "ferrovia do agronegócio", já que a principal mercadoria transportada nesse sistema de movimento são grãos ou produtos relacionados com a agricultura (fertilizantes, fungicidas, herbicidas, entre outros); os terminais de cargas multimodais, bem como os armazéns são majoritariamente controlados por tradings agrícolas (Bunge, Cargill, Agrex do Brasil, Algar Agro, entre outros), indicando que esta ferrovia é especializada na circulação de commodities agrícolas voltadas para o mercado externo.

A partir de 2001, o porto de Itaqui passa a ser controlado pela Empresa Maranhense de Administração Portuária (EMAP), e é nesse momento que observa-se a construção de uma materialidade voltada especificamente para as commodities agrícolas, como a construção de um berço para embarcar grãos produzidos nos Cerrados do MATOPIBA, bem como o Terminal de Grãos do Maranhão (TEGRAM). O Tegram é um terminal que contém armazéns com capacidade de 500 mil t de grãos, sendo resultado de esforços do Estado, já que colaborou com $R \$ 245$ milhões em financiamento, via BNDES, com as empresas (tradings agrícolas) que administram o terminal - CGG, Nova Agri, Glencore e a joint venture entre a Amaggi e Louis Dreyfus Commodities (EMAP, 2016). Tais articulações do Estado com o mercado demonstram que não se pode considerar as commodities apenas como uma manifestação financeira e econômica, mas também como um fenômeno geográfico que tem sérias implicações territoriais como a estruturação de novos objetos geográficos que buscam facilitar a fluidez para as corporações que controlam diferentes etapas do processo produtivo do circuito espacial da soja, influenciando assim no próprio ordenamento territorial.

Percebe-se que há uma "commoditização" regional decorrente das articulações políticas e técnicas, entre o Estado e o mercado, dotando o MATOPIBA de novos fixos, como a ferrovia Norte/Sul e a modernização do Porto de Itaqui, que produzem novos fluxos de mercadoria e ordens. Toda esta configuração provoca a complexização das redes agroindustriais (ELIAS, 2006) na região do MATOPIBA, provindos dos nexos produtivos das grandes empresas do agronegócio (agroindústrias e tradings). A instalação destas empresas, responsáveis pela comercialização e algumas pela industrialização de grãos são fundamentais para a conformação de um novo arranjo produtivo agrícola, propiciando a intensificação da divisão territorial do trabalho, bem como a especialização regional na produção de commodities. Neste sentido a "commoditização" do território.

\section{SUPEREXPLORAÇÃO DO TRABALHO E DOS RECURSOS NATURAIS NO MATOPIBA}

Como já discutido, os ganhos de produtividade decorrentes da exploração de novos espaços para as atividades agrícolas (como no caso do MATOPIBA) bem como aqueles decorrentes da intensificação do pacote tecnológico, foram importantes na sustentação da inserção especializada do Brasil na divisão internacional do trabalho após os anos 2000. Esse processo trouxe situações que devem ser discutidas, como a superexploração do trabalho e dos recursos naturais. Trata-se de fatores que, como afirma Delgado (2012) não entram no cálculo da produção agrícola e que acarretam custos sociais significativos, ou como aponta Harvey (2016), seria mais um esquema de despossessão.

Uma das implicações do avanço dos monocultivos no MATOPIBA é a exploração dos recursos naturais, tendo como uma de suas características mais marcantes, o aumento do desmatamento da vegetação do principal bioma dessa região, os Cerrados. Segundo dados do Ministério do Meio Ambiente (MMA, 2009; 2011a; 2011b) entre 2002 e 2010 nos Cerrados, o desmatamento aproximado nos estados do Maranhão, Tocantins, Bahia e Tocantins foi respectivamente de $18.750 \mathrm{~km}^{2}(9 \%)$, $14.479 \mathrm{~km}^{2}(5,7 \%), 10.992 \mathrm{~km}^{2}(7,24 \%)$ e $5.893 \mathrm{~km}^{2}$ (5,75\%) da vegetação em cada estado. Cabe mencionar que entre 2009-2010, o estado do Maranhão aparece, como o estado brasileiro onde houve maior desflorestamento, $1.587 \mathrm{Km}^{2}(0,75 \%)$; em segundo o Piauí a área desmatada chegou a $979 \mathrm{~km}^{2}(1,05 \%)$; o terceiro foi o Tocantins, que chegou a $970 \mathrm{Km}^{2}(0,38 \%)$; e, em quarto lugar a Bahia com $726 \mathrm{~km}^{2}$ (0,48 (MMA, 2011b). Além disso, entre 2002 e 2010 os municípios que mais desmataram os Cerrados foram justamente os localizados no MATOPBIA, com destaque aos municípios do oeste baiano (Tabela 2). 
Tabela 2 - Municípios que mais desmataram no bioma dos Cerrados por km² (2002-2010).

\begin{tabular}{lcccc}
\hline \multicolumn{1}{c}{ Municípios } & $2002-2008$ & $2008-2009$ & $2009-2010$ & Total \\
\hline Formosa do Rio Preto (BA) * & 2.003 & 197 & 144 & 2.344 \\
São Desidério (BA) * $^{*}$ Correntina (BA) * & 1.329 & 124 & 120 & 1.573 \\
Paranatinga (MT) & 1.284 & 126 & 36 & 1.446 \\
Baixa Grande do Ribeira (PI) * & 1.054 & 107 & 67 & 1.228 \\
Balsas (MA) * & 662 & 168 & 394 & 1.224 \\
Barra do Corda (MA) * & 862 & 93 & 85 & 1.040 \\
Jaborandi (BA) * & 874 & 83 & 30 & 987 \\
Barreiras (BA) * & 724 & 131 & 33 & 888 \\
Nova Ubiratã (MT) & 616 & 111 & 88 & 815 \\
Brasnorte (MT) & 766 & 18 & 25 & 809 \\
Uruçuí (PI) * & 792 & 7 & 6 & 805 \\
Grajaú (MA) * & 548 & 50 & 203 & 801 \\
Sapezal (MT) & 608 & 100 & 69 & 777 \\
Riachão das Neves (BA) * & 697 & 14 & 22 & 733 \\
Nova Mutum (MT) & 545 & 56 & 69 & 670 \\
São José do Rio Claro (MT) & 621 & 2 & 14 & 637 \\
Codó (MA) * & 616 & 6 & 4 & 626 \\
Crixás (GO) & 386 & 122 & 70 & 578 \\
Santa Rita do Trivelato (MT) & 491 & 31 & 43 & 565 \\
\hline
\end{tabular}

Fonte - MMA (2009; 2011a; 2011b). Org.: Autores. * Municípios presentes no MATOPIBA.

Tais dados sinalizam que o crescimento do desmatamento dos Cerrados está relacionado com o aprofundamento da especialização regional na produção de grãos, visto que os municípios com o maior registro de desmatamento são aqueles com maior orientação à atividade agrícola científica, como Formosa do Rio Preto (BA), São Desidério (BA), Barreiras (BA), Uruçuí (PI), Baixa Grande do Ribeira (PI), Balsas (MA), entre outros importantes municípios que cultivam soja. Também cabe mencionar que é justamente neste período, 2002 a 2010, que diferentes empresas voltadas para a especulação fundiária intensificaram as suas atuações no MATOPIBA, tais como SLC Agrícola, Sollus Capital, Brasil Agrícola e Adecoagro, que sozinhas possuem o controle de aproximadamente 215 mil ha de terras na região (SOUZA, 2017). Estas corporações, juntamente com outras empresas do setor, estão colaborando para a verticalização do desflorestamento do bioma, bem como geração de inúmeras outras consequências ambientais tais como diminuição da biodiversidade (fauna e flora), aumento do assoreamento dos cursos d'águas, seca de rios, interferência no regime de chuvas, contaminação do solo e da água pelo uso de agrotóxicos, entre outros.

Além disso, as relações entre a população local e as atividades da agricultura científica globalizada são, muitas das vezes, conturbadas e conflituosas. Assim é no Oeste baiano, onde a população tem se indignado e protestado contra os grandes produtores de commodities que usam de forma inadequada e abusiva, os recursos hídricos dos municípios. Um exemplo é o caso de Correntina (BA), com especial atenção para o rio Arrojado - afluente do rio Corrente. De acordo com Gomes (2017), a empresa japonesa Igarashi, que possui fazendas para produção de algodão e grãos nesse município consumiu sozinha, 100 vezes mais água do que toda a população da cidade -12 mil habitantes em 2010 (IBGE, 2017). Em 2015 esta empresa foi autorizada (via outorga d'água, pelo Instituto Estadual do Meio Ambiente) a retirar um volume aproximado de $182.203 \mathrm{~m}^{3}$ por dia do rio Arrojado, esta quantidade poderia ser o bastante para abastecer mais de 6,6 mil cisternas domésticas de 16 mil litros na região do semiárido (GOMES, 2017).

Em termos gerais, a superexploração dos recursos naturais traz consequências sérias para o meio ambiente e consequentemente para a sociedade como um todo. No oeste baiano, por exemplo, estudos mostram que 15 pequenos rios secaram nos últimos anos devido a vários fatores entre eles, o uso de pivôs centrais para irrigação (SILVA, 2017b). O uso intensivo dos recursos hídricos se relaciona com a irrigação por pivô central, já que o Oeste baiano é uma das regiões que mais utiliza este sistema técnico na produção agrícola no MATOPIBA. Desta maneira, observam-se problemas com relação ao abastecimento de água para a população, no campo e nas cidades, já que o pivô central drena significativa quantidade de água dos rios (MONTEIRO, 2017).

$\begin{array}{lllll}\text { Caminhos de Geografia } \quad \text { Uberlândia } & \text { v. 20, n. } 72 & \text { Dez/2019 } & \text { p. 149-168 Página } 161\end{array}$


Neste sentido observa-se que a inserção regional na economia internacional através da produção de commodities, vem se afirmando a partir da exploração dos recursos naturais, tendo como uma de suas expressões o crescente desmatamento dos Cerrados e o uso abusivo dos recursos hídricos pelos grandes produtores agrícolas. Esta situação nos sinaliza que expansão da fronteira agrícola para esta região está sendo realizada de forma predatória, destruindo recursos ambientais essenciais para a vida cotidiana das populações. Assim, a devastação de recursos naturais vai muito além dos prejuízos e perdas ambientais, sendo também um problema de ordem social.

A superexploração não se resume apenas aos aspectos naturais do uso do território, mas ocorre também em outras esferas, como a social. A primarização da pauta exportadora como opção de inserção competitiva do Brasil na divisão internacional do trabalho traz implicações, como a superexploração do trabalho. Trata-se de um fator pertinente para pensarmos a situação dependente do Brasil de acordo com as proposições teóricas de Marini (1973).

Em termos gerais as atividades que envolvem a produção de commodities são as principais mantenedoras de situações de superexploração do trabalho como as situações de trabalho análogas à escravidão. A Organização Internacional do Trabalho (OIT) define essas situações como:

[...] trabalho degradante aliado ao cerceamento da liberdade. Este segundo fator nem sempre é visível, uma vez que não mais se utilizam correntes para prender o homem à terra, mas sim ameaças físicas, terror psicológico ou mesmo as grandes distâncias que separam a propriedade da cidade mais próxima (OIT, 2006, p. 27).

O cerceamento da liberdade, fator essencial para a compreensão do trabalho análogo ao escravo, ocorre comumente pela servidão por dívida, ou seja, quando bens essenciais como alimentação, higiene, moradia e até mesmo equipamentos de trabalho não são fornecidos pelo contratante. Mas sim, comercializados com preços altos e deduzidos da remuneração do trabalhador, criando situações onde o trabalhador não consegue saldar sua dívida. Portanto, findar seu contrato de trabalho, ou ainda pela retenção de documentos, pela dificuldade de acesso ao local e, muitas vezes, pela presença de guardas armados (OIT, 2006). Associada a essa situação temos a presença de alojamentos precários, falta de equipamentos de segurança, acesso a serviços de saúde, alimentação em contrato "cativo", onde a alimentação do trabalhador é fornecida a preços exorbitantes pelo contratante e descontada no preço de sua remuneração, e muitas vezes o trabalho infantil.

Dados da Comissão Pastoral da Terra (CPT) mostram que no Brasil, entre 1986 e 2012, foram registradas denúncias que juntas somaram 165.808 trabalhadores submetidos a essas condições de superexploração do trabalho e, quase no mesmo período, entre 1995 e 2012, o Ministério do Trabalho e Emprego (MTE), por meio de suas frentes fiscalizadoras "libertaram" 44.425 trabalhadores (GIRARDI et al., 2014). Grande parte desses casos se concentraram na pecuária (que lidera o ranking das denúncias no Brasil) e em outras atividades agrícolas, na mineração, na carvoaria e no desmatamento. Mesmo em atividades com considerável desenvolvimento tecnológico e com mecanização há situações de superexploração do trabalho, como no caso do setor sucroenergético, por exemplo, que ocupa o segundo lugar no ranking de denúncias.

Uma pesquisa realizada pela OIT, em 2011, com os trabalhadores resgatados naquele ano, revelou uma característica importante para pensar a questão dessas situações de trabalho análogas à escravidão. Ao perguntarem aos trabalhadores qual seria, na visão deles, a solução para o problema, $46,1 \%$ responderam "ter terra para plantar" e ter um emprego rural registrado (13,5\%), outras respostas incluíam ter um comércio $(26,9 \%)$ e ter um emprego na cidade $(13,5 \%)$ (OIT, 2011). Esses dados evidenciam a origem desses trabalhadores (meio rural) e como a questão do trabalho análogo a escravidão deve ser pensando em consonância com a questão agrária brasileira.

Uma leitura da questão contemporânea do trabalho escravo (GIRARDI et al., 2014) nos mostra que a região do MATOPIBA possui altos índices de probabilidade de trabalho análogo à escravidão e de vulnerabilidade ao aliciamento, o que se relaciona com o fato de ser a mais recente expansão agrícola nos Cerrados e que leva consigo todas as implicações territoriais advindas desse processo como a concentração fundiária, expulsão de trabalhadores do campo e instalação de regimes de monocultivo (Figuras 3 e 4).

Caminhos de Geografia Uberlândia $\quad$ v. 20, n. $72 \quad$ Dez/2019 $\quad$ p. 149-168 Página 162


Figura 3 - Número de trabalhadores em situação de trabalho análogo ao escravo (2001 - 2015).

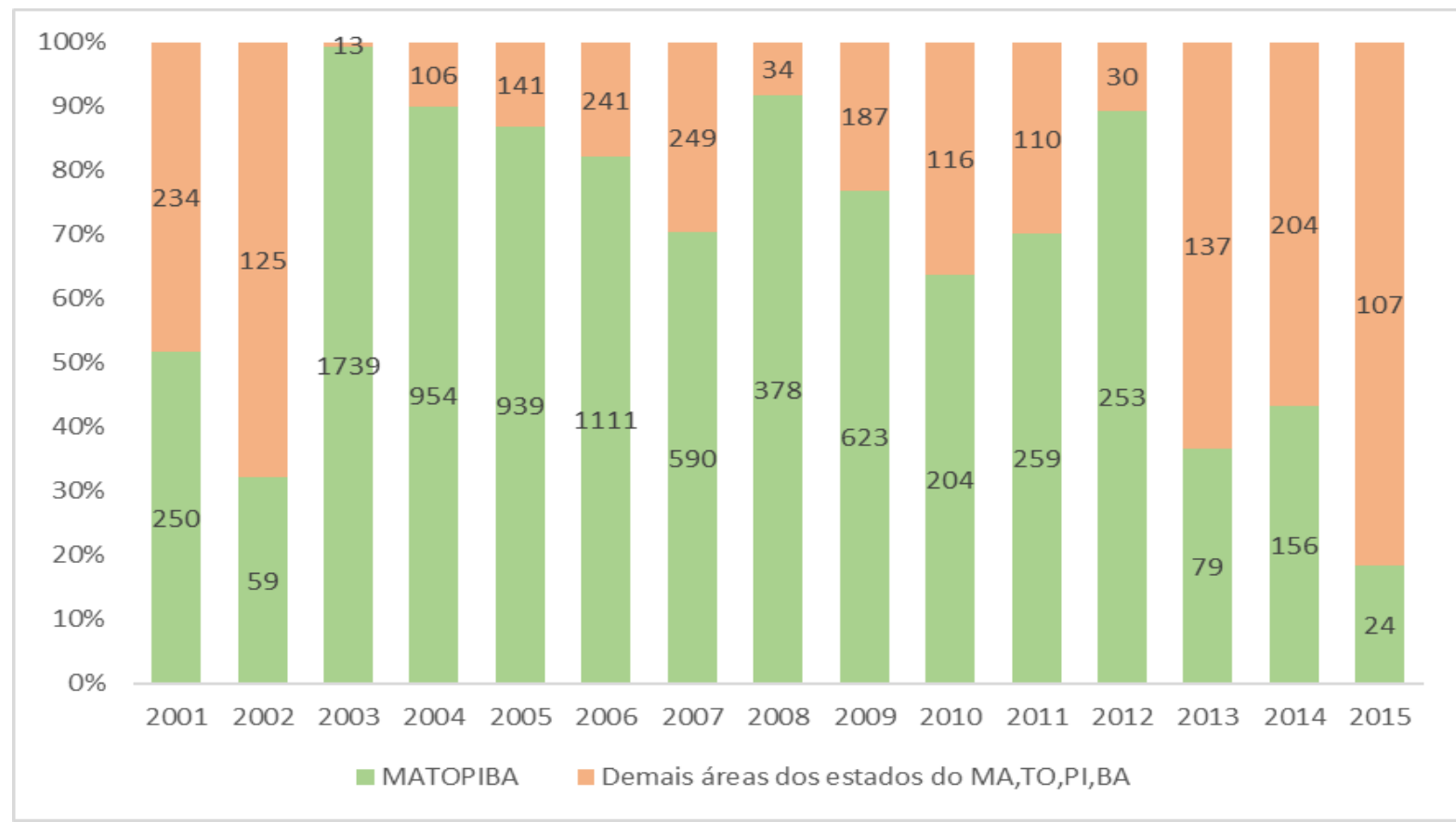

Fonte - REPORTER BRASIL, 2017. Org.: Autores.

Figura 4 - Número de registros de trabalho escravo (2001 - 2015).

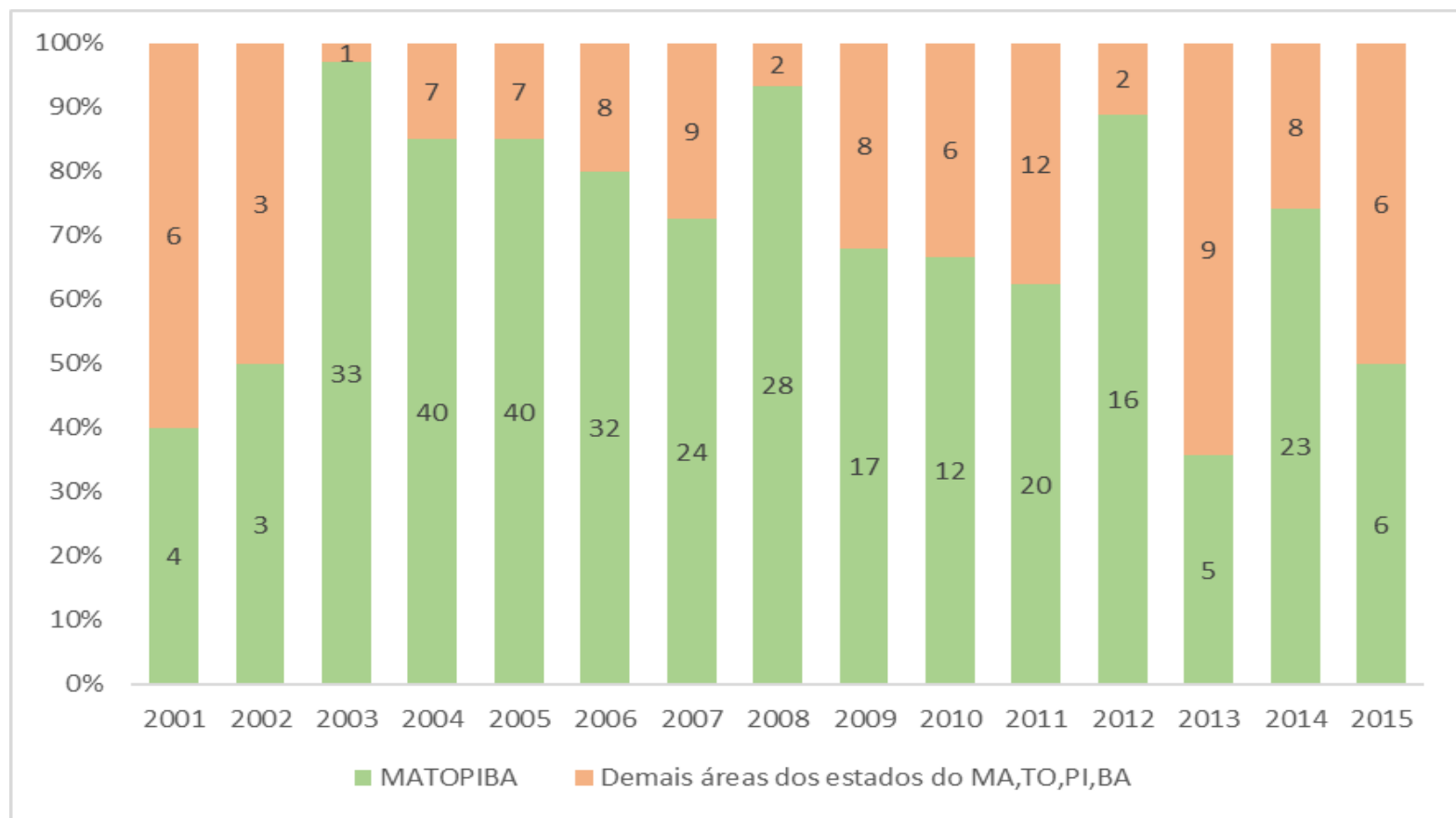

Fonte - REPORTER BRASIL, 2017. Org.: Autores.

A partir da análise dos gráficos pode-se atestar a expressiva quantidade de casos de trabalho análogo ao escravo que se concentram nos municípios inseridos na região do MATOPIBA. Pode-se perceber também que entre 2003 e 2012, o MATOPIBA concentrou mais da metade dos casos, tanto de registros quanto de número de trabalhadores, com destaque especificamente para 2003, quando o

Caminhos de Geografia $\quad$ Uberlândia $\quad$ v. 20, n. $72 \quad$ Dez/2019 $\quad$ p. 149-168 Página 163


percentual alcança quase os $100 \%$. Em 2003 foram realizados 33 registros que contabilizaram 1.739 trabalhadores "escravizados" no MATOPIBA (REPÓRTER BRASIL, 2017).

Como exemplo desses casos pode-se citar o resgate de 53 pessoas em uma fazenda em Correntina (BA), que realizava atividades agrícolas relacionadas ao setor de papel e celulose (G1, 2011a) ocorrido em 2011. Ainda no mesmo ano, outras 30 pessoas foram resgatadas de uma fazenda em Barreira (BA), onde trabalhavam na coleta do milho que não era alcançado pelas colheitadeiras, 0 que indica, por exemplo, a presença desse tipo de situação mesmo em atividades onde a mecanização é realidade $(G 1,2011 b)$. Mais recentemente, em 2017, diversos empresários que atuam no Oeste baiano apareceram na última "lista suja" divulgada pelo MTE (lista que divulga os empresários e empresas autuados por condições de trabalho análogas ao escravo), com atividades em fazendas nos municípios de São Desidério, Cristópolis e Barreiras (BAHIANOTÍ́CIAS, 2017).

No entanto essas situações não se resumem ao Oeste baiano. Em 2012, uma estimativa do até então Ministério do Desenvolvimento Agrário (MDA), atual Secretaria Especial de Agricultura Familiar e do Desenvolvimento Agrário da Casa Civil da Presidência da República (SEAD), afirmava que 38\% dos trabalhadores em condições análogas à escravidão no Brasil estavam no Maranhão, o que correspondia a no mínimo 9,5 mil trabalhadores (PORTAL BRASIL, 2012). Em 2017, 52 procedimentos de autuação estavam em curso no Ministério Público do Trabalho no Maranhão, sendo que 32 envolviam condições degradantes de trabalho, 11 envolviam jornada exaustiva, 6 envolviam servidão por dívida e 3 envolviam submissão ao trabalho forçado (G1, 2017a).

Já na "lista suja" do MTE estão quatro empregadores do estado do Maranhão com atividades majoritariamente agrícola nos municípios de Imperatriz, Brejo da Areia, Miranda do Norte e São Pedro da Água Branca (G1, 2017b). Em 2017 no Tocantins foram 21 empregadores, em sua maioria fazendas $(G 1,2017 \mathrm{c})$. Em 2012, por exemplo, foram registradas 17 fiscalizações no estado do Tocantins, sendo 16 dessas em fazendas, totalizando 315 trabalhadores resgatados (REPORTER BRASIL, 2012). O estado do Piauí, por sua vez, soma 6 empregadores na "lista suja" de 2017 do MTE, sobretudo concentrados nas atividades extrativistas. No total, 98 trabalhadores estavam envolvidos com esses empregadores (CIDADE VERDE, 2017). No entanto, outras atividades também concentraram situações desse tipo, como a extração de madeira e a carvoaria. Nesses ramos, 42 trabalhadores foram resgatados só em 2017 no Piauí (G1, 2017d).

Silva Junior et al. (2015) analisando os dados da CPT que abarcam os conflitos por terra, água e por questões socioambientais, mostram que entre 2000 e 2015 foram registrados 1.643 conflitos na região do MATOPIBA. Esses conflitos estão relacionados, sobretudo, à ameaça de expropriação, a expulsão e despejo de camponeses e povos tradicionais, à destruição e poluição de mananciais, bem como diminuição do acesso à água, e à reassentamentos inadequados. Esses conflitos envolveram principalmente, de um lado, posseiros, assentados, quilombolas e trabalhadores sem-terra e, de outro, empresários, fazendeiros e grileiros (SILVA JUNIOR et al., 2015). Tais dados demonstram como a expansão do agronegócio na região vem implicando em sérios problemas de cunho ambiental e social no território brasileiro.

\section{CONSIDERAÇÕES FINAIS}

Consideramos que as medidas políticas e econômicas adotadas pelo Estado nos últimos anos, de apostar na reafirmação da pauta exportadora de produtos primários de baixo valor agregado para gerar saldos positivos na balança comercial, vem promovendo ou mesmo acentuando a subordinação do território brasileiro às incertezas da economia globalizada sob a égide do capital financeiro.

Esse processo acaba por reafirmar a inserção dependente do Brasil no contexto do mercado mundial, através da afirmação da produção de commodities como vantagem comparativa. A centralidade do setor primário na inserção brasileira no mercado mundial acarreta consequências para o território que, operacionalizado para suprir demandas exógenas, acaba fragmentado e vulnerável. Para o território esse processo resulta em superexploração dos recursos naturais e do trabalho, o que para a sociedade implica em situações de precarização do trabalho cada vez mais recorrentes.

O agronegócio no Brasil está sendo cada vez mais regido pela lógica das finanças, o que reforça a condição de vulnerabilidade do país, uma vez que há a crescente especialização regional na produção de commodities agrícolas, cuja constituição se orienta a partir da volatilidade do capital financeiro. Desta maneira, o território nacional fica alheio a articulações políticas e econômicas que

Caminhos de Geografia Uberlândia $\quad$ v. 20, n. $72 \quad$ Dez/2019 $\quad$ p. 149-168 Página 164


fogem do controle da sociedade, ficando "refém" de lógicas e intenções que são definidas por um conjunto específico de agentes nacionais e internacionais.

Este processo de financeirização da atividade agrícola no Brasil, que junto ao processo de desenvolvimento da agricultura científica globalizada acarretou a expansão das fronteiras agrícolas para o interior dos Cerrados, é sustentado por meio da superexploração dos recursos naturais e do trabalho. A principal implicação para o território brasileiro quando situações geográficas como a do MATOPIBA se consolidam, é sua reafirmação como espaço subordinado à acumulação do capital, apropriada pelos países centrais da economia capitalista. Para a sociedade tem-se um ônus significativo, oriundo da superexploração do trabalho e dos recursos naturais, muitas vezes, financiada com recursos da própria nação como recursos do PAC, via BNDES, por exemplo. A razão desse processo é a necessidade cada vez maior de remuneração dos agentes do capital financeiro e, consequentemente, dos agentes envolvidos, o que leva à busca pelo aumento da mais-valia que ocorre através da superexploração do trabalho e dos recursos naturais. No entanto, a partir da análise podemos considerar que esses mecanismos são perversos e acarretam situações graves, tanto do ponto de vista social quanto ambiental, que não são contabilizadas nos custos das atividades econômicas.

Assim, acreditamos que é preciso pensar em novos modos e estratégias de inserção do Brasil na divisão internacional do trabalho que priorize a emancipação do país como um todo, que não seja pautada nos interesses de uma pequena parcela da sociedade e que não seja orientado de forma hegemônica por interesses exógenos. Acredita-se também que é preciso repensar as práticas que envolvem a expansão das atividades agrícolas no Brasil, considerando o respeito pelos direitos humanos, a busca pela equidade social e pela democratização do uso do território.

\section{AGRADECIMENTOS}

Os resultados compartilhados nesse artigo foram resultantes de pesquisas de mestrados financiados pela Fundação de Amparo a Pesquisa de Minas Gerais - FAPEMIG (no caso do primeiro autor) e pelo Conselho Nacional de Desenvolvimento Científico e Tecnológico - CNPQ (no caso do segundo autor).

\section{REFERÊNCIAS}

AB'SABER, Aziz Nacib. Os domínios de natureza no Brasil, potencialidades paisagísticas. São Paulo: Ateliê Editorial, 2003.

ALVES, V. E. L. Mobilização e modernização nos Cerrados piauienses: formação territorial no império do agronegócio. 2006. 320 f. Tese (Doutorado) - Faculdade de Filosofia, Letras e Ciências Humanas, Universidade de São Paulo, São Paulo, 2006.

Prefácio. In: ALVES, Vicente Eudes Lemos (Org.). Modernização e regionalização nos Cerrados do Centro-Norte do Brasil. Rio de Janeiro: Consequência, 2015.

AMARAL, M. S. Breves considerações acerca das teorias do imperialismo e da dependência ante a financeirização do capitalismo contemporâneo. Pensata. Revista dos Alunos do Programa de PósGraduação em Ciências Sociais da UNIFESP, v. 3, p. 80-96, 2013.

BAHIA NOTÍCIAS. Oeste baiano: empresários são citados em nova lista suja do trabalho escravo. 2017. Disponível em: <http://www.bahianoticias.com.br>. Acesso em: 06 de Dez. 2017.

BERNARDES, Julia Adão. Fronteiras da agricultura moderna no Cerrado Norte/Nordeste: descontinuidades e permanências". In: BERNARDES, Julia Adão; BRANDÃO FILHO, José Bertoldo (Org.). Geografias da soja II: a territorialidade do capital. Rio de Janeiro: Arquimedes/CNPq, 2009. p. $13-40$. 
BERNARDES, J. A.; MALDONADO, G. Estratégias do capital na fronteira agrícola moderna brasileira e argentina. In: BERNARDES, J. A. et al. (Org.). Globalização do agronegócio e land grabbing: a atuação das megaempresas argentinas no Brasil. Rio de Janeiro: Lamparina, 2017. p.57-80.

CASTILLO, R. Região competitiva e logística: expressões geográficas da produção e da circulação no período atual. Seminário Internacional Sobre Desenvolvimento Regional, 4., 2008, Santa Cruz do Sul. Anais... . Santa Cruz do Sul: Unisc, 2008. p.1-19.

. Agricultura globalizada e logística nos Cerrados brasileiros. In: SILVEIRA, M. R. (Org.).

Circulação, transportes e logística diferentes perspectivas. São Paulo: Outras expressões, 2011. p.331-354.

CASTILLO, R.; SAMUEL, F. Dinâmica regional e globalização: espaços competitivos agrícolas no território brasileiro. Mercator, Fortaleza, v. 9, n. 18, p.17-26, Jan/Abr. 2010a. https://doi.org/10.4215/RM2010.0918.0002

Espaço geográfico, produção e movimento: uma reflexão sobre o conceito de circuito espacial produtivo. Sociedade e Natureza, Uberlândia, v. 3, n. 22, p.461-473, dez. $2010 \mathrm{~b}$. https://doi.org/10.1590/S1982-45132010000300004

CHESNAIS, F. O capital portador de juros: acumulação, internacionalização, efeitos econômicos e políticos. In: CHESNAIS, F. (Org.). A finança mundializada: raízes e políticas, configuração, consequências. São Paulo: Boitempo, 2005. p.35-68.

. A proeminência da finança no seio do "capital em geral", o capital fictício e o movimento contemporâneo de mundialização do capital. In: BRUNHOFF, S., et al. (org.). A finança capitalista. São Paulo: Alameda Casa Editorial, 2010. p. 95-183.

CIDADE VERDE. Seis empresas do Piauí estão em lista de autuados por trabalho escravo.2017. Disponível em: <https://cidadeverde.com>. Acesso em: 06 de Dez. 2017.

DELGADO, G. Do capital financeiro na agricultura à economia do agronegócio: mudanças cíclicas em meio século (1965-2012). Porto Alegre: UFRGS, 2012.

Especialização primária como limite ao desenvolvimento. Desenvolvimento em debate. Rio de Janeiro, v.1, n.2, p.111-125, jan/abr.; mai./ago. 2010.

ELIAS, D. Redes agroindustriais e produção do espaço urbano no Brasil agrícola. In: SILVA, J. B. et al (Org). Panorama da geografia brasileira I. São Paulo: Annablume, 2006. p. 221-239.

. Agronegócio e novas regionalizações no Brasil. Revista Brasileira de Estudos Urbanos e Regionais (ANPUR), [s/i], v.13, n.2, p. 153-170, 2011. https://doi.org/10.22296/23171529.2011v13n2p153

EMPRESA MARANHENSE DE ADMINISTRAÇÃO PORTUÁRIA - EMAP. 2016. Infraestrutura. Disponível em: < http://www.emap.ma.gov.br/>. Acesso em: 08 Jul. 2016.

FORNARO, A. C. Logística e Agronegócio Globalizado no Estado do Tocantins: um estudo sobre a expansão das fronteiras agrícolas modernas no território brasileiro. 2012. 175 f. Dissertação (Mestrado) - Curso de Geografia, Universidade Estadual de Campinas, Campinas, 2012.

FREDERICO, S. Imperativos da exportação e especialização agrícola no território brasileiro: das regiões competitivas às regiões cooperativas. Revista Geografia, Rio Claro, v. 36, p.5-18, 2012.

Economia política do território e as forças de dispersão e concentração no agronegócio brasileiro. Geographia, Rio de Janeiro, v.17, n.35, p.68-94, 2015. https://doi.org/10.22409/GEOgraphia2015.1735.a13729

FREDERICO, S.; GRAS, C. Globalização financeira e land grabbing: constituição e translatinização das megaempresas argentinas. In: BERNARDES, J. A. et al (org.). Globalização do agronegócio e land grabbing: a atuação das megaempresas argentinas no Brasil. Rio de Janeiros: Lamparina, 2017. p.12-32.

G1. Fiscalização resgata 53 pessoas de trabalho escravo em Correntina-BA. 2011a. Disponível em: <http://g1.globo.com>. Acesso em: 06 de Dez. 2017. 
G1. Fazendeiro é condenado por manter trabalho escravo na Bahia. 2011b. Disponível em: <http://g1.globo>. Acesso em: 06 de Dez. 2017.

G1. Trabalho escravo no Maranhão ocorre em condições degradantes em mais de $60 \%$ casos. 2017a. Disponível em: <https://g1.globo.com>. Acesso em: 06 de Dez. 2017.

G1. Maranhão possui quatro nomes na lista suja do trabalho escravo. 2017b. Disponível em: <https://g1.globo.com>. Acesso em: 05 de Dez. 2017.

G1. Tocantins tem 21 empregadores em lista sobre trabalho escravo. 2017c. Disponível em: <http://g1.globo.com>. Acesso em: 06 de Dez. 2017.

G1. Trabalhadores em situação análoga à de escravos no Piauí receberam carvão como pagamento, diz procurador. 2017d. Disponível em: <https://g1.globo.com>. Acesso em: 05 de Dez. 2017.

GIRARDI, E. P. et al. Mapeamento do trabalho escravo contemporâneo no Brasil: dinâmicas recentes. Espaço e Economia. São Gonçalo, ano II, n. 4, 2014. https://doi.org/10.4000/espacoeconomia.804

GOMES, M. Brasil de fato. Guerra da água no Oeste da Bahia. 2017. Disponível em: $<$ https://www.brasildefato.com.br>. Acesso em: 08 Jan. 2018.

HARVEY, D. Contradição 11: Desenvolvimentos Geográficos Desiguais e Produção de Espaço. In: . Dezessete contradições e o fim do capitalismo. São Paulo: Boitempo, 2016. p. 139-152.

MARINI, R. M. Dialética da Dependência. 1973. Disponível em: <https://www.marxists.org>. Acesso em: 15 de Nov. 2016.

MINISTÉRIO DA INDÚSTRIA, COMÉRCIO EXTERIOR E SERVIÇOS - MDIC. Balança Comercial Brasileira. Disponível em: <http://www.mdic.gov.br>. Acesso em: 16 de Dez. 2017.

MINISTÉRIO DO MEIO AMBIENTE - MMA. Relatório Técnico De Monitoramento Do Desmatamento No Bioma Cerrados, 2002 a 2008; 2008-2009; 2009-2010. Dados Revisados. Brasília: Centro de Informação, Documentação Ambiental, 2009; 2011a; 2011b. Disponível em: <http://www.mma.gov.br>. Acesso em: 28 de Nov. 2015.

MONTEIRO, A. Correntina Insurgente: uma guerra da água no Brasil. Ecodebate. Recife, 16 de nov. 2017. Disponível em: <https://www.ecodebate.com.br>. Acesso em: 17 de Dez. 2017.

OIT - ORGANIZAÇÃO INTERNACIONAL DO TRABALHO. Trabalho escravo no Brasil do Século XXI. Brasília: OIT, 2006. Disponível em: <http://www.oitbrasil.org.br>. Acesso em: 17 de Dez. 2017. OIT, 2011.

Perfil dos principais atores envolvidos no trabalho escravo rural no Brasil. Brasília:

PITTA, F. T.; MENDONÇA, M. L. A empresa Radar S/A e a especulação com terras no Brasil. São Paulo: Outras Expressões, 2015. v. 1. p.58.

PORTAL BRASIL. MDA debate combate ao trabalho escravo no maranhão. 2012. Disponível em: $<$ http://www.brasil.gov.br>. Acesso em: 05 de Dez. 2017.

EPORTER BRASIL. Dados sobre trabalho escravo no Brasil. 2017. Página na internet. Disponível em: <http://reporterbrasil.org.br/>. Acesso em: 05 de Dez. 2017.

SANTOS, M. Modo de produção técnico-científico e diferenciação espacial. São Paulo, Território. n. 6, Jan/Jul 1999.

A natureza do espaço. Técnica e tempo. Razão e emoção. São Paulo: Edusp, 2002.

Por uma outra globalização. Do pensamento único à consciência universal. Rio de Janeiro: Record, 2001.

SANTOS, M.; SILVEIRA, M. L. S. O Brasil: território e sociedade no início do século XXI. Rio de Janeiro: BestBolso, 2011. https://doi.org/10.5654/actageo2011.0001.0011

SISTEMA IBGE DE RECUPERAÇÃO AUTOMÁTICA - SIDRA. Produção Agrícola Municipal. 2016. Disponível em: <http://www.sidra.ibge.gov.br>. Acesso em: 22 Jun. 2016. 
SILVA JUNIOR, J. et al. A pílula dourada do agrohidronegócio, o MATOPIBA. 2015. Disponível em: <https://www.cptnacional.org.br>. Acesso em: 05 de Dez. 2017.

SILVA, L. R. O BNDES e a sustentação do setor sucroenergético no brasil: implicações territoriais no contexto neoliberal e de financeirização. Dissertação (Mestrado) - Curso de Geografia, Universidade Federal de Uberlândia, Uberlândia, 2017 a.

SILVA, J. Quinze rios do oeste baiano secam por causa da destruição do Cerrados. IASB, 11 de dez. 2017. Disponível em: <http://iasb.org.br/noticia/quinze-rios-do-oeste-baiano-secam-por-causa-dadestruicao-do-Cerrados>. Acesso em: 05 de Dez. 2017b.

SOUZA, G. V. A. A elaboração da viabilidade territorial para o agronegócio na região do MATOPIBA. 2017. 194 f. Dissertação (Mestrado) - Curso de Geografia, Universidade Federal de Uberlândia, Uberlândia, 2017.

VENCOVSKY, V. P. Ferrovia e logística do agronegócio globalizado: Avaliação das políticas públicas e privadas do sistema ferroviário brasileiro. 198 f. Tese (Doutorado) - Curso de Geografia, Universidade de Campinas, Campinas, 2011.

i

Recebido em: 13/06/2018

Aceito para publicação em: 26/11/2019 